\title{
Analisis Kesuksesan Sistem Informasi Kemahasiswaan (SIKMA) dengan Pendekatan Model DeLone dan McLean
}

\author{
F S Rahayu ${ }^{* 1}$, R Apriliyanto ${ }^{2}$, Y S P W Putro ${ }^{3}$ \\ ${ }^{1}$ Prodi Sistem Informasi, Universitas Atma Jaya Yogyakarta, J1. Babarsari 43 \\ Jogjakarta 55281 \\ ${ }^{2,3}$ Prodi Teknik Informatika, Universitas Atma Jaya Yogyakarta, Jl. Babarsari 43 \\ Jogjakarta 55281
}

E-mail: sapty.rahayu@uajy.ac.id ${ }^{* 1}$,robert.aprlynt@gmail.com², sigit.purnomo@uajy.ac.id ${ }^{3}$

Masuk: 6 Agustus 2018, direvisi: 26 Agustus 2018, diterima: 28 Agustus 2018

\begin{abstract}
Abstrak. Implementasi sistem informasi pada sebuah organisasi perlu dievaluasi apakah implementasi tersebut telah dapat dikatakan sukses dan berdampak positif bagi pengguna. Sistem Informasi Kemahasiswaan yang digunakan oleh Universitas Atma Jaya Yogyakarta dikembangkan sebagai sarana mahasiswa dalam mengumpulkan nilai Satuan Partisipasi Aktivitas Mahasiswa Atma Jaya (SPAMA). Melalui sistem ini, setiap mahasiswa dapat mengembangkan potensi-potensi yang dimilikinya. Selama ini belum pernah dilakukan evaluasi terhadap kesuksesan implementasinya. Penelitian ini bertujuan untuk mengukur pengaruh system quality, information quality dan service quality terhadap user satisfaction dan use serta mengetahui net benefits dari penggunaan sistem informasi terkait. Model yang digunakan adalah model kesuksesan sistem informasi Delone \& McLean 2003. Terdapat 10 hipotesis yang diuji menggunakan model Structural Equation Modelling (SEM). Dari 10 hipotesis yang diuji, lima dinyatakan diterima dan lima dinyatakan ditolak.
\end{abstract}

Kata kunci: Analisis Kesuksesan, Sistem Informasi Kemahasiswaan, Model DeLone \& McLean

\begin{abstract}
The implementation of information systems in an organization needs to be evaluated whether the implementation can be considered as successful and have a positive impact to the user. Sistem Informasi Kemahasiswaan (Students Information System) used by Universitas Atma Jaya Yogyakarta is developed as a students' facility to collect grades of Satuan Partisipasi Aktivitas Mahasiswa Atma Jaya (SPAMA). Through this system, every student will be able to improve skills they have. The evaluation has never been conducted in the past few years. This research is aimed to measure the effect of system quality, information quality, and service quality towards user satisfaction and use, and find out the net benefits from information system related. The model used is information systems success model by Delone \& McLean (2003). There are 10 hypothesis tested using Structural Equation Modelling (SEM) model. From the 10 tested hypothesis, five of them are accepted while the other five are rejected
\end{abstract}

Keywords: Success Analysis, Students Information System, DeLone \& McLean Model 


\section{Pendahuluan}

Keberadaan sistem informasi dalam sebuah organisasi sekarang ini bukan lagi hanya sebagai sistem pendukung melainkan menjadi sistem yang harus ada bahkan ikut menentukan keberhasilan suatu organisasi. Sistem yang didukung Teknologi Informasi dapat memberikan nilai lebih bagi organisasi jika didesain menjadi sistem informasi yang efektif dan efisien. Tetapi pengukuran atau penilaian kualitas sistem informasi yang efektif tidak mudah untuk dilakukan [1].

Penelitian Roldan \& Leal [2] menyatakan bahwa kualitas sistem dan informasi merupakan prediktor yang signifikan terhadap kepuasan pemakai, pengunaan dan dampak individu. Kepuasan pengguna didefinisikan sebagai daya terima pengguna terhadap sistem, dan keuntungan menyeluruh adalah sejauh mana Sistem Informasi memberikan kontribusi bagi keberhasilan individu, kelompok, ataupun organisasi [3]. Beberapa penelitian yang lain menunjukkan bahwa kualitas sistem dan informasi merupakan prediktor yang signifikan terhadap penggunaan, namun tidak signifikan terhadap kepuasan pemakai.

Kesuksesan sistem informasi bisa dipandang dari beberapa hal seperti seberapa bagus kualitas sistem, informasi yang diberikan, bagaimana tingkat penggunaan, dan kepuasan penggunaan serta hal lain yang menunjukkan seberapa besar efek yang diperoleh dengan adanya sistem informasi tersebut [4]. Satu dari sekian banyak model yang dapat digunakan untuk mengukur kesuksesan sebuah sistem informasi adalah model yang diberikan oleh William H. DeLone dan Ephraim R. McLean, yang terdiri dari enam faktor pengukur kesuksesan sistem informasi. Teori ini kemudian dikembangkan pada tahun 2003 dengan menambahkan kualitas service (service quality) dan menggabungkan dampak individu (individual impact) serta dampak organisasi (organization impact) menjadi manfaat-manfaat bersih (net benefits) [5].

Sistem Informasi Kemahasiswaan (SIKMA) digunakan mahasiswa UAJY untuk melakukan prosedur pengisian Satuan Partisipasi Aktivitas Atma Jaya (SPAMA). Mahasiswa yang diwajibkan untuk ambil bagian dalam SPAMA adalah semua mahasiswa UAJY angkatan 2011 ke atas. Penerapan SPAMA dilakukan karena disamping membutuhkan kecerdasan intelektual, mahasiswa diharapkan juga diharapkan mengembangkan soft skill sehingga terjadi keseimbangan antara prestasi akademik dan pembentukan karakter mahasiswa.

Selama ini belum pernah dilakukan evaluasi terhadap kesuksesan penggunaan SIKMA sehingga belum diketahui apakah sistem ini benar-benar sudah efekif dan efisien untuk menjawab kebutuhan mahasiswa. Berdasarkan kebutuhan tersebut penelitian ini dilakukan untuk mengukur sejauh mana tingkat kesuksesan penggunaan SIKMA. Tingkat kesuksesan akan diukur dari dampak, manfaat dan kepuasan pengguna setelah menggunakan SIKMA. Untuk mengukur tingkat kesuksesan tersebut, digunakan model pengukur kesuksesan sistem informasi DeLone dan McLean dalam penelitian ini. Model ini dipilih karena dianggap mampu untuk menjelaskan evaluasi sistem dari sisi pengguna yaitu kepuasan pengguna. Hasil dari evaluasi diharapkan dapat digunakan sebagai panduan untuk memperbaiki atau mengoptimalkan fungsi SIKMA.

\section{Kerangka Teoritis}

Untuk mengukur tingkat kesuksesan dari sebuah sistem informasi, dibutuhkan sebuah model dalam menganalisa faktor-faktor terkait kesuksesannya. DeLone dan McLean [6] menciptakan model kesuksesan sistem informasi dan menyarankan bahwa para periset harus "secara sistematis mengkombinasikan ukuran-ukuran individu dari kategori kesuksesan sistem informasi untuk menciptakan sebuah instrumen pengukur kesuksesan yang komprehensif'. Berdasarkan pada riset mengenai komunikasi yang dilakukan oleh Shannon \& Weaver [7] dan teori pengaruh informasi oleh Mason [8], maupun studi empiris yang dilakukan oleh Management Information Systems (MIS) pada tahun 1981-1987, sebuah model kesuksesan sistem informasi yang komprehensif dan multidimensi dikembangkan. Riset komunikasi yang dilakukan oleh Shannon dan Weaver menyatakan bahwa komunikasi di dalam sebuah sistem informasi terbentuk atas tiga level. Pertama, technical level dari komunikasi adalah akurasi dan efisiensi dari sistem komunikasi yang memproduksi informasi. Kedua, Semantic level adalah kesuksesan dari informasi dalam menyampaikan makna yang sesuai. Ketiga, Effectiveness level adalah efek dari informasi pada penerima informasi. Dalam model kesuksesan 
DeLone dan McLean, tiga level komunikasi tersebut dibagi ke dalam enam dimensi. System quality mengukur kesuksesan secara technical; Information quality mengukur kesuksesan secara semantic; dan use, user satisfaction, individual impacts dan organizational impact mengukur kesuksesan secara effectiveness [6].

DeLone dan McLean pada tahun 2003, memperbaiki serta mengusulkan model yang sudah diperbarui,ditunjukkan pada gambar 1 , untuk digunakan pada kasus e-commerce.

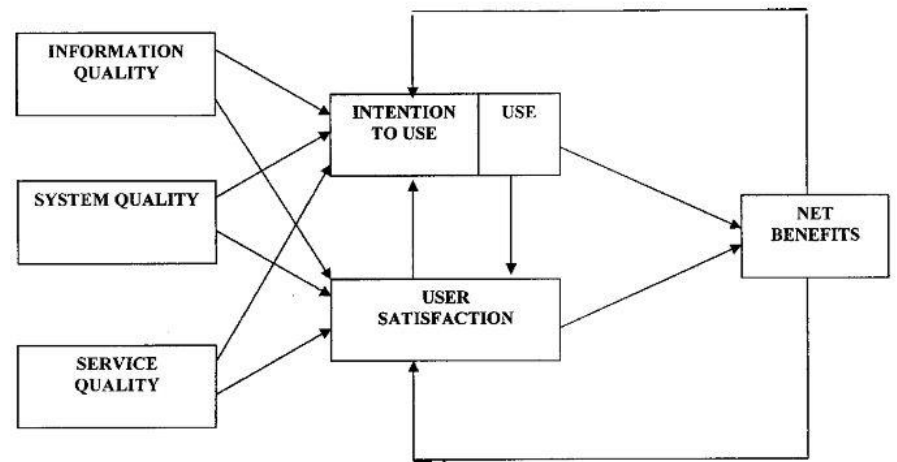

Gambar 1. Model Kesuksesan Sistem Informasi DeLone \& McLean 2003

Berikut adalah uraian dari masing-masing variabel:

1. Kualitas Sistem (System Quality)

Kualitas sistem mencakup sejauh mana performa yang ditunjukkan oleh sistem ketika user menggunakan sistem informasi, baik dari segi hardware maupun dari segi software. Indikator pengukuran kualitas sistem antara lain adalah kemudahan untuk digunakan (ease of use), fleksibilitas (flexibility), keandalan sistem (reliability), kecepatan akses (response time), dan keamanan sistem (security).

2. Kualitas Informasi (Information Quality)

Variabel ini menggambarkan kualitas informasi yang diharapkan oleh pengguna ketika memakai sistem. Indikator pengukuran kualitas informasi meliputi ketersediaan/kelengkapan informasi (completeness), kemudahan pemahaman (ease of understanding), penyajian informasi (format), relevansi kebutuhan (relevance), dan keakurasian informasi (accurate).

3. Kualitas Layanan (Service Quality)

Pengguna sistem informasi mengharapkan pelayanan yang sesuai ekspektasi ketika menggunakan sebuah sistem informasi. Variabel ini menjamin adanya layanan yang diberikan oleh sistem informasi, seperti update dan respon terhadap feedback yang diberikan oleh pengguna. Indikator pengukur kualitas layanan meliputi jaminan sistem (assurance), empati (empathy), dan waktu respon layanan (responsiveness).

4. Pemakaian (Use)

Variabel ini mengacu pada seberapa sering pengguna memakai sistem informasi. Indikator pengukuran pemakaian meliputi semua hal tentang kebiasaan penggunaan sistem, seperti frequency of use dan nature of use.

5. Kepuasan Pengguna (User Satisfaction)

Variabel ini merupakan respon dan tanggapan yang diajukan oleh pengguna setelah memakai sistem informasi. Variabel pengukur kepuasan pengguna adalah efisiensi (efficiency), efektifitas (effectiveness), dan kepuasan menyeluruh (overall satisfaction).

6. Manfaat-Manfaat Bersih (Net Benefits)

Variabel ini merupakan dampak keberadaan serta pemakaian sistem informasi terhadap kualitas kinerja pengguna baik secara individu maupun organisasi. Variabel pengukur manfaat-manfaat bersih adalah peningkatan kinerja, efisiensi dan efektifitas, dan produktifitas.

Telah banyak penelitian terapan terhadap Sistem Informasi yang dilakukan menggunakan model kesuksesan DeLone dan McLean. Diantaranya penelitian Radityo \& Zulaikha [9] yang mengambil

Rahayu, Apriliyanto, Putro (Analisis Kesuksesan Sistem Informasi Kemahasiswaan (SIKMA) dengan Pendekatan Model DeLone dan McLean) 
kasus penggunaan aplikasi SIMAWEB (Sistem Informasi Akademik Berbasis Website) pada Fakultas Ekonomi Universitas Diponegoro, Salim [10] yang mengambil kasus Sistem Informasi Perpustakaan Senayan di SMK Muhammadiyah 3 Yogyakarta, Budiyanto [11] yang mengambil kasus pada implementasi Billing System di RSUD Kabupaten Sragen, dan Purwaningsih [12] melakukan penelitian mengenai Analisis Kesuksesan Penerapan Sistem Informasi pada Sistem Informasi Pelayanan Terpadu (SIPT) Online.

Penelitian di atas menunjukkan bahwa konteks pemakaian sistem informasi voluntari dan mandatori menghasilkan hasil yang berbeda. Model DeLone dan McLean 2003 lebih sesuai diterapkan untuk pemakaian sistem informasi yang bersifat voluntari. Hal ini terbukti dengan didukungnya model secara empiris oleh beberapa penelitian dalam sistem informasi voluntari [10]. Sedangkan pada penelitian lain yang bersifat mandatori [9], [11], [12] menunjukkan ketidaktepatan pengukuran variabel penggunaan oleh variabel lain dalam model DeLone dan McLean tahun 1992. Oleh karena itu, dalam penelitian ini digunakan model DeLone dan McLean yang diperbarui [5] untuk membuktikan secara empiris cocok tidaknya model tersebut pada sistem informasi yang mandatori.

\section{Metodologi Penelitian}

\subsection{Populasi dan Sampel}

Populasi yang digunakan adalah seluruh mahasiswa aktif Universitas Atma Jaya Yogyakarta yang menggunakan SIKMA sebagai sarana pengelolaan data SPAMA. Metode sampling yang digunakan adalah random sampling atau penarikan sampel acak. Dikarenakan sifat SIKMA yang mandatori oleh karena itu tidak dibutuhkan kriteria tertentu dalam menentukan sampel. Penentuan sampel yang dipilih sebagai responden adalah mahasiswa aktif angkatan 2011-2015 dengan target 200 mahasiswa yang mencakup semua program studi di semua fakultas, baik kelas regular maupun internasional. Jumlah sampel adalah 205 orang berdasarkan jumlah orang yang mengembalikan daftar dari pertanyaan yang telah diajukan. Periode penelitian kuesioner berlangsung dari 4 Maret 2016 sampai 13 Mei 2016.

\subsection{Model dan Hipotesis Penelitian}

Beberapa penelitian menunjukkan bahwa antara satu dimensi dengan dimensi lainnya saling berhubungan satu sama lain, sehingga diperlukan sebuah hipotesis untuk membentuk keterkaitan. Menurut Urbach et al. [13] hubungan asosiatif yang paling signifikan dalam model keberhasilan sistem informasi DeLone dan McLean adalah antara kualitas sistem dengan kepuasan end-user. Selain itu, hubungan antara kualitas informasi (Information Quality) dengan kepuasan pengguna (User Satisfaction), penggunaan sistem (Use) dengan kepuasan pengguna (User Satisfaction), serta kualitas sistem (System Quality) dengan penggunaaan sistem (Use).

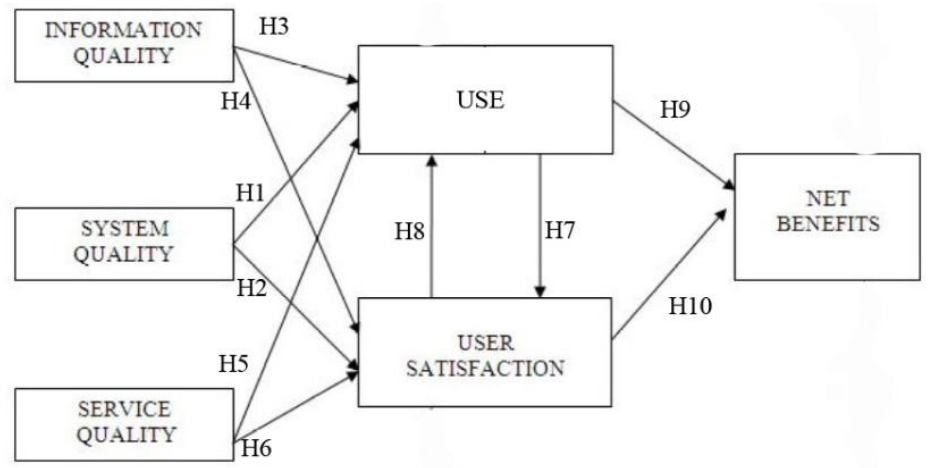

Gambar 2. Model DeLone dan McLean berdasarkan hipotesis

Hipotesis yang akan diuji dalam penelitian ini, ditunjukkan pada gambar 2, sesuai dengan penelitian Wang \& Liao [14] yaitu:

H1 : Kualitas sistem (system quality) mempunyai pengaruh positif terhadap penggunaan (use).

Rahayu, Apriliyanto, Putro (Analisis Kesuksesan Sistem Informasi Kemahasiswaan (SIKMA) dengan Pendekatan Model DeLone dan McLean) 
H2 : Kualitas sistem (system quality) mempunyai pengaruh positif terhadap kepuasan pengguna (user satisfaction).

H3 : Kualitas informasi (information quality) mempunyai pengaruh positif terhadap penggunaan (use).

H4 : Kualitas informasi (information quality) mempunyai pengaruh positif terhadap kepuasan pengguna (user satisfaction).

H5 : Kualitas layanan (service quality) mempunyai pengaruh positif terhadap penggunaan (use).

H6: Kualitas layanan (service quality) mempunyai pengaruh positif terhadap kepuasan pengguna (user satisfaction).

H7 : Penggunaan (use) mempunyai pengaruh positif terhadap kepuasan pengguna (user satisfaction).

H8 : Kepuasan pengguna (user satisfaction) mempunyai pengaruh positif terhadap penggunaan (use).

H9 : Penggunaan (use) mempunyai pengaruh positif terhadap manfaat-manfaat bersih (net benefits).

H10 : Kepuasan pengguna (user satisfaction) mempunyai pengaruh positif terhadap manfaatmanfaat bersih (net benefits).

\subsection{Metode Pengumpulan Data}

Metode yang digunakan untuk pengumpulan data adalah metode kuesioner. Dari model DeLone dan McLean 2003 yang sudah ditentukan sebelumnya didapatkan prediktor atau variabel penelitian yang digunakan. Variabel tersebut selanjutnya dibedakan menjadi dua antara lain variabel bebas (independen) dan variabel terikat (dependen). Tiga variabel bebas adalah information quality, system quality, dan service quality. Tiga variabel terikat atau dependen adalah Use, User Satisfaction, dan Net Benefits.

Kualitas Sistem (System Quality) yang dimaksud dalam penelitian adalah karakteristik dari SIKMA seperti kemudahan dalam penggunaan, keandalan sistem, kecepatan akses, fleksibilitas sistem serta keamanan. Kualitas Informasi (Information Quality) yang dimaksud dalam penelitian ini mengukur kualitas output dari SIKMA. Kualitas Layanan (Service Quality) yang dimaksud dalam penelitian adalah mengukur kualitas layanan yang diberikan oleh SIKMA. Kualitas layanan yang diberikan seperti jaminan dalam penggunaan, waktu respon layanan dan bentuk respon yang sesuai. Variabel Penggunaan (Use) yang dimaksud dalam penelitian ini adalah tanggapan penggunaan sistem informasi oleh end user atas kesadaran dan keinginan pengguna sendiri. Penggunaan meliputi keseluruhan penggunaan SIKMA serta interaksi melalui navigasi dalam website. Variabel Kepuasan pengguna (User Satisfaction) yang dimaksud dalam penelitian ini adalah tanggapan dari pengguna SIKMA terhadap kinerja sistem. Kepuasan pengguna meliputi cara mencari informasi tentang input data pengguna SIKMA melalui sistem, informasi dan layanan. Variabel Manfaat Bersih (Net Benefits) yang dimaksud dalam penelitian ini merupakan dampak pemakaian SIKMA terhadap pengguna meliputi efisiensi dan efektifitas SIKMA. Jumlah pertanyaan kuesioner untuk semua variabel terdiri dari 5 pertanyaan yang diukur menggunakan skala Likert, mulai dari Sangat Tidak Setuju (1) hingga Sangat Setuju (5).

Masing-masing variabel penelitian terdiri dari indikator-indikator. Variabel system quality terdiri dari indikator kemudahan untuk digunakan (ease of use), fleksibilitas sistem (flexibility), keandalan sistem (reliability), kecepatan akses (response time), dan keamanan sistem (security). Variabel information quality terdiri dari indikator kelengkapan (completeness), penyajian informasi (format), relevansi (relevance), keakuratan (accurate), dan mudah dipahami (understandability). Variabel service quality terdiri dari indikator waktu respon (responsiveness), empati (empathy), dan jaminan (assurance). Variabel use terdiri dari indikator sifat penggunaan (nature of use) dan frekuensi penggunaan (frequency of use). Variabel user satisfaction terdiri dari indikator efektivitas (effectivity), efisiensi (efficiency), dan kepuasan menyeluruh (overall satisfaction). Variabel net benefits terdiri dari indikator manfaat soft skills (benefits to soft skills) dan motivasi (motivation). 


\subsection{Alat Bantu Peneltian}

Alat bantu penelitian yang digunakan adalah software SPSS dan AMOS yang menggunakan model SEM (Structural Equation Model).

\subsection{Tahapan Penelitian}

Secara garis besar langkah-langkah di dalam penelitian ini dirangkum pada diagram alir penelitian seperti ditunjukkan pada gambar 3.

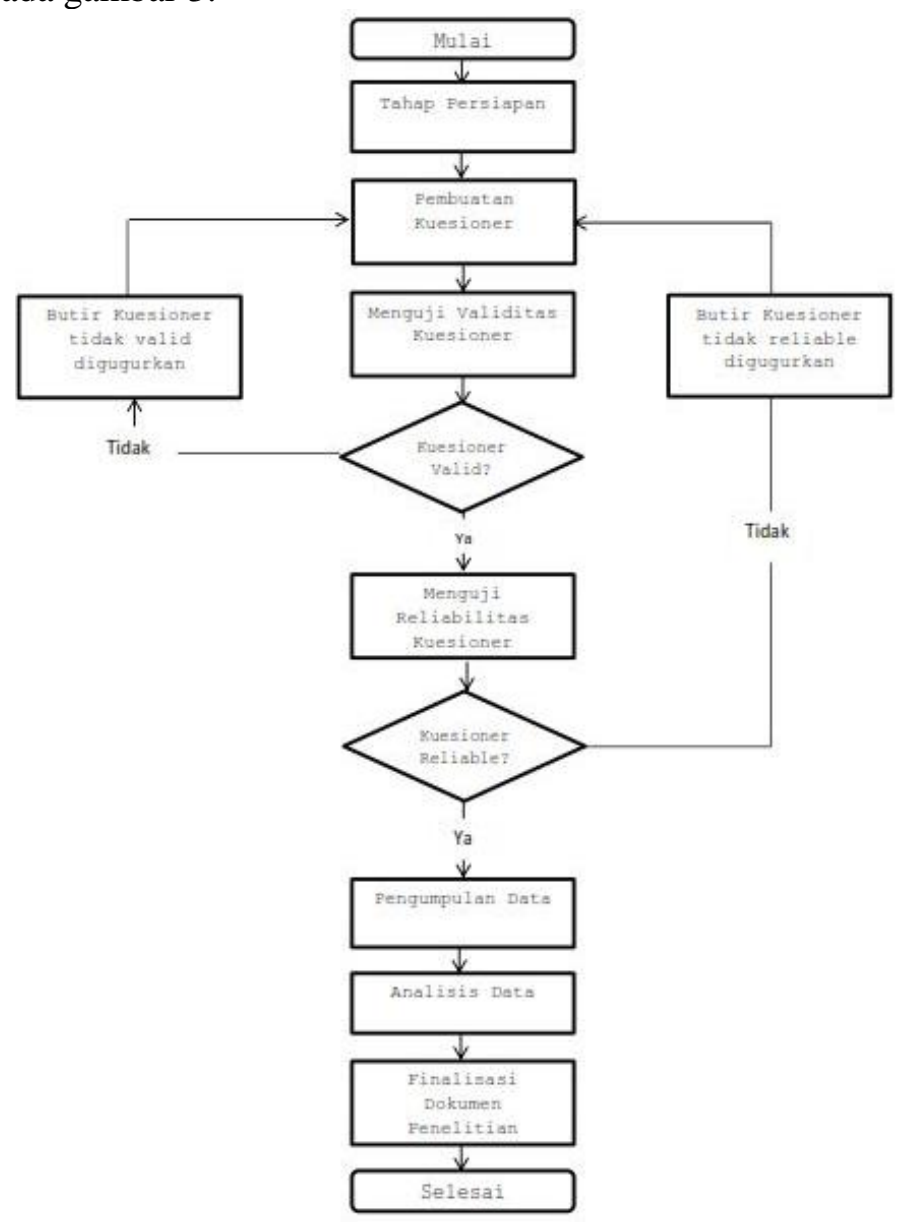

Gambar 3. Diagram Alir Penelitian

\subsection{Tahapan Analisa dan Pengolahan Data}

Untuk menguji kuesioner dilakukan uji validitas dan uji reliabilitas.Uji reliabilitas dalam penelitian ini yang dipakai adalah cronbach alpha $(\alpha)$ dengan nilai variabel lebih besar dari 0,7 .

\subsection{Analisis Structural Equation Modelling (SEM)}

Setelah uji validasi dan reliabilitas, dilakukan analisis SEM (Structural Equation Modelling). Analisis yang termasuk dalam SEM antara lain analisis faktor, analisis jalur, dan regresi. Tahapan-tahapan dalam analisis SEM adalah sebagai berikut :

1. Pengembangan model berdasarkan teori, path diagram kesuksesan SIKMA UAJY ditunjukkan pada gambar 4.

2. Pengembangan Diagram Alur.

3. Mengkonversi Diagram Alur ke dalam Persamaan Struktural.

4. Evaluasi Asumsi dan Kesesuaian Model. 
5. Yang terdiri dari analisis normalitas, uji asumsi klasik (uji linearitas dan multikolinearitas), uji kesesuaian model. Indeks kesesuaian dan out off value ditunjukkan pada tabel 1.

6. Interpretasi (Hipotesis dan Hubungan Kausal)

7. Modifikasi Model

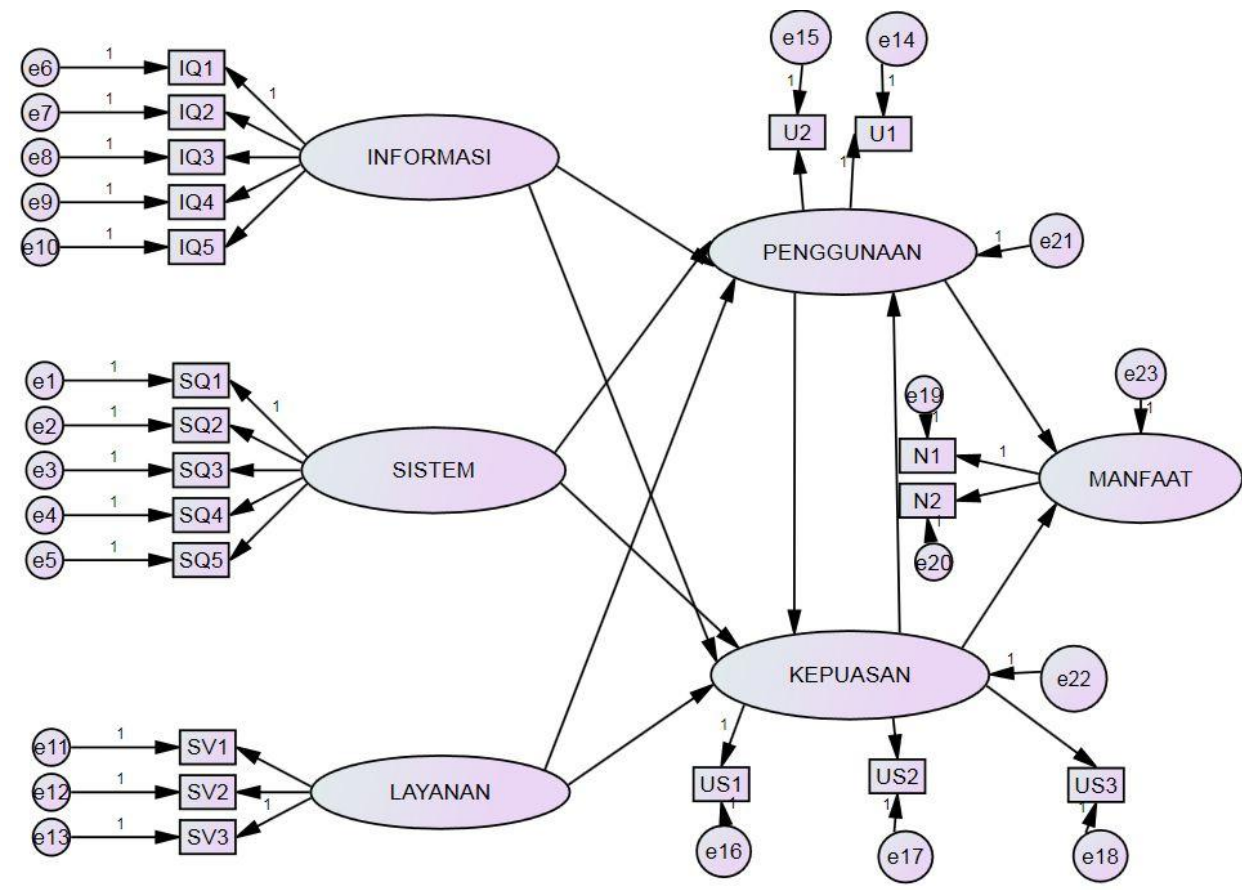

Gambar 4. Path Diagram Kesuksesan SIKMA UAJY

Tabel 1. Uji Goodness of Fit [15]

\begin{tabular}{cc}
\hline Goodness of Fit index & Kriteria \\
\hline Chi-square Significant & Harus \\
Probability & kecil \\
RMSEA & $\geq 0,05$ \\
GFI & $\leq 0,08$ \\
AGFI & $\geq 0,90$ \\
CMIN/DF & $\geq 0,90$ \\
TLI & $\leq 2,00$ \\
CFI & $\geq 0,90$ \\
NFI & $\geq 0,90$ \\
& $\geq 0,90$ \\
\hline
\end{tabular}

\section{Hasil dan Pembahasan}

Dari kuesioner terkumpul sebanyak 205 buah (100\%), terdapat 3 data $(1,45 \%)$ yang tidak lengkap. Sehingga total data yang didapat dan layak untuk dianalisa berjumlah 202 data $(98,55 \%)$.

\subsection{Hasil Uji Validitas Data}

Dasar pengambilan keputusan dalam uji validitas adalah:

1. Jika nilai $\mathrm{r}$ hitung $>\mathrm{r}$ tabel, maka item pertanyaan atau pertanyaan dalam kuesioner berkorelasi signifikan terhadap skor total (valid).

2. Jika nilai $r$ hitung $<\mathrm{r}$ tabel, maka item pertanyaan atau pertanyaan dalam kuesioner tidak berkorelasi signifikan terhadap skor total (tidak valid). 
Pada penelitian ini akan dilakukan uji validitas konstruk dilakukan dengan menggunakan SPSS 22. Tiap-tiap variabel diukur per indikator dan dibandingkan dengan skor $r$ tabel. Nilai $r$ tabel untuk signifikansi 0,05 (5\%) dan $\mathrm{N}=202$ adalah 0,138 [16].

Tabel 2. Hasil Uji Validitas Indikator Konstruk

\begin{tabular}{cccc}
\hline Indikator & Hasil Uji $(\mathbf{r}$ hitung $)$ & R Tabel $=\mathbf{2 0 2}(\mathbf{r}$ tabel $)$ & Keterangan \\
\hline SQ1 & $.691^{* * *}$ & 0,138 & Valid \\
SQ2 & $.717^{* *}$ & 0,138 & Valid \\
SQ3 & $.497^{* *}$ & 0,138 & Valid \\
SQ4 & $.598^{* *}$ & 0,138 & Valid \\
SQ5 & $.605^{* *}$ & 0,138 & Valid \\
IQ1 & $.671^{* *}$ & 0,138 & Valid \\
IQ2 & $.629^{* *}$ & 0,138 & Valid \\
IQ3 & $.677^{* *}$ & 0,138 & Valid \\
IQ4 & $.563^{* *}$ & 0,138 & Valid \\
IQ5 & $.544^{* *}$ & 0,138 & Valid \\
SV1 & $.368^{* *}$ & 0,138 & Valid \\
SV2 & $.614^{* *}$ & 0,138 & Valid \\
SV3 & $.552^{* *}$ & 0,138 & Valid \\
U1 & $.589^{* *}$ & 0,138 & Valid \\
U2 & $.597^{* *}$ & 0,138 & Valid \\
US1 & $.644^{* *}$ & 0,138 & Valid \\
US2 & $.613^{* *}$ & 0,138 & Valid \\
US3 & $.595^{* *}$ & 0,138 & Valid \\
N1 & $.403^{* *}$ & 0,138 & Valid \\
N2 & $.473^{* *}$ & 0,138 & Valid \\
\hline
\end{tabular}

Berdasarkan tabel 2, masing-masing indikator dari semua konstruk dinyatakan valid, karena nilai hasil uji validitasnya (r hitung) semua diatas nilai $r$ tabel yaitu 0,138 .

\subsection{Hasil Uji Reliabilitas Data}

Reliabilitas yang tinggi ditunjukkan dengan nilai rxx mendekati angka 1. Uji reliabilitas dianggap sudah cukup memuaskan jika $\geq 0,700$. Masing-masing indikator akan dihitung nilai cronbach alphanya yang kemudian dibandingkan dengan nilai alpha pada populasi 202 responden yaitu 0,138. Pada penelitian ini semua indikator dinyatakan reliabel karena nilai hasil uji reliabilitasnya di atas $r$ tabel yaitu 0,138 serta berada di antara 0.80 dan 1.00 yang menyatakan bahwa hubungan antar alat ukur sangat erat.

\subsection{Analisis Structural Equation Modelling (SEM)}

Untuk menguji hipotesis yang telah ditentukan sebelumnya, dilakukan uji statistik dengan perhitungan Structural Equation Modelling (SEM) sebagai analisis kuantitatif. Sebelum melakukan analisis uji hipotesis menggunakan SEM, terdapat beberapa prasyarat yang harus dipenuhi sehingga model SEM dapat memenuhi kriteria goodness of fit.

\subsubsection{Uji Asumsi Model Structural Equation Modelling (SEM)}

\subsubsection{Uji Asumsi Kecukupan Sampel}

Hair dalam Ghozali \& Fuad [17] menyatakan bahwa "sampel minimum adalah 5 kali jumlah variabel manifest (indikator)". Pada penelitian ini dihitung jumlah sampel minimal yaitu 20 (jumlah indikator) 
dikali 5 sehingga minimal sampel 100 orang. Jumlah data yang terkumpul adalah 202 sampel data sehingga dinyatakan cukup.

\subsubsection{Uji Normalitas}

Pada pengujian ini diamati nilai skewness dan kurtosis data yang digunakan, jika nilai CR pada skewness dan CR pada kurtosis berada di antara -2,58 dan 2,58, maka data penelitian yang digunakan dapat dikatakan normal. Pada penelitian ini sebagian besar nilai CR terdapat di antara -2,58 dan 2,58 (kecuali item $\mathrm{N} 2=-3.179$ ) sehingga dapat disimpulkan secara univariate sudah baik walaupun terdapat indikator yang tidak normal akan tetapi data tersebut masih dapat dikatakan terdistribusi secara normal. Hair [18] menyebutkan bahwa data yang normal secara multivariate juga akan normal secara univariate.

\subsubsection{Uji Asumsi Klasik}

\subsubsection{Linearitas}

Uji Linearitas digunakan untuk menguji apakah model yang dibangun mempunyai hubungan linear atau tidak. Hubungan yang diuji adalah hubungan antara variabel independen dan dependen. Dasar pengukuran linearitas hubungan antar variabel adalah jika nilai signifikansi berada di bawah 0,05 dan nilai f Hitung lebih besar f Tabel 0,05 yaitu 3,88. Uji Linearitas dilakukan dengan menggunakan SPSS.Pada uji linearitas ini hubungan antara variabel independen dan dependen terbukti linear. Hal ini dikarenakan nilai signifikansi hitung berada di bawah signifikansi 0,05 dan nilai f Hitung lebih besar dari nilai f Tabel (df1 : 1, df $2: 200$ ) yaitu 3,88.

\subsubsection{Multikolinearitas}

Pada penelitian ini, uji asumsi klasik Multikolinearitas digunakan untuk mengukur tingkat asosiasi (keeratan) hubungan antar variabel independen melalui nilai VIF (Variance Inflation factor). Dasar pengukuran nilai VIF untuk multikolinieritas adalah jika VIF < 3; tidak ada masalah, VIF > 3; berpotensi masalah, VIF > 5; sangat mungkin masalah, VIF > 10; bermasalah. Variabel independen yang diuji dalam penelitian ini adalah Kualitas Sistem, Kualitas Informasi dan Kualitas Layanan.

Pada uji multikolinearitas ini, hubungan antar variabel independen terbukti tidak memiliki masalah multikolinieritas karena nilai VIF hitung berada di bawah 3 .

\subsubsection{Analisa Kesesuaian Model (Goodness-of-fit)}

Agar dapat melanjutkan ke tahap SEM, perlu dilakukan pengujian goodness of fit dengan hasil yang baik. Hal pertama yang dilakukan adalah dengan uji goodness of fit pada model yang belum dimodifikasi.

Tabel 3. Goodness of Fit Index

\begin{tabular}{cccc}
\hline Goodness of Fit Index & Kriteria & Cut of Value & Keterangan \\
\hline Chi-square & $<$ Chi-Square DF (124.342) & 288.936 & Tidak baik \\
Prob. & $\geq 0.05$ & .000 & Tidak Baik \\
RMSEA & $\leq 0.08$ & .066 & Baik \\
GFI & $\geq 0.90$ & .870 & Marginal Fit \\
CMIN/DF & $\leq 2.00$ & 1.864 & Baik \\
TLI & $\geq 0.90$ & .901 & Baik \\
CFI & $\geq 0.90$ & .919 & Baik \\
NFI & $\geq 0.90$ & .843 & Marginal \\
RFI & $\geq 0.90$ & .808 & Marginal \\
IFI & $\geq 0.90$ & .921 & Baik \\
\hline
\end{tabular}


Berdasarkan hasil pengujian goodness of fit index yang ditunjukkan pada tabel 3, diketahui sebagian besar masuk kriteria yang ada maka dapat disimpulkan bahwa model berada pada kondisi baik (fit). Akan tetapi, masih ada hasil yang tidak memenuhi kriteria antara lain chi-square dan probabilitas. Oleh karena itu, dilakukan uji goodness of fit dengan menggunakan model SEM dengan variabel composite.

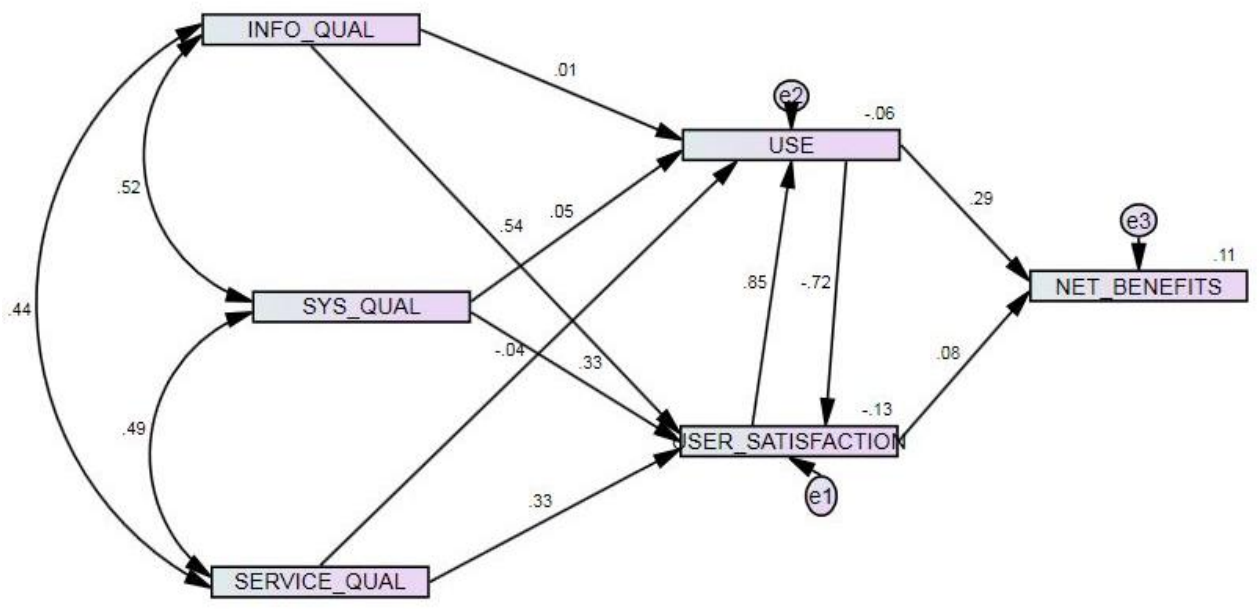

Gambar 5. Composite Path Diagram

Variabel composite digunakan karena telah melewati uji common method bias dan termasuk common latent factor di dalam tiap-tiap variabelnya. Composite Path Diagram yang digunakan ditunjukkan pada gambar 5. Hasil uji goodness of fit dengan model SEM composite dapat dilihat pada tabel 4.

Tabel 4. Goodness of Fit Index Model Composite

\begin{tabular}{lccc}
\hline Goodness of Fit Index & Kriteria & Cut off Value & Keterangan \\
\hline Chi-square & $<$ Chi-Square DF $(7.815)$ & 4.896 & Baik \\
Prob. & $\geq 0.05$ & .173 & Baik \\
RMSEA & $\leq 0.08$ & .057 & Baik \\
GFI & $\geq 0.90$ & .992 & Baik \\
CMIN/DF & $\leq 2.00$ & 1.662 & Baik \\
TLI & $\geq 0.90$ & .967 & Baik \\
CFI & $\geq 0.90$ & .993 & Baik \\
NFI & $\geq 0.90$ & .984 & Baik \\
RFI & $\geq 0.90$ & .921 & Baik \\
IFI & $\geq 0.90$ & .994 & Baik \\
\hline
\end{tabular}

Dari tabel 4, hasil pengujian goodness of fit dengan menggunakan model composite diketahui semua index masuk kriteria baik.

\subsubsection{Analisis Koefisien Jalur Path Analysis Structrual Equation Modeling (SEM)}

Pengujian model dalam SEM dilaksanakan dengan dua pengujian, yaitu uji kesesuaian model dan uji signifikansi kausalitas melalui uji koefisien regresi. Path Diagram yang digunakan dalam uji signifikansi kausalitas ini adalah model dengan variabel Composite. Penggunaan model ini digunakan tanpa mengubah dasar model penelitian dan tetap sesuai kerangka penelitian. Uji hipotesis dilakukan dengan cara menganalisis nilai regresi. Sesudah memenuhi syarat, uji berikutnya adalah uji regression weight. Uji ini dilakukan sama dengan uji t terhadap regression weight/factor loading koefisien model. Hasil uji regresi ditunjukkan pada tabel 5. 
Tabel 5. Regression Weights Analisis SEM

\begin{tabular}{lcccccl}
\hline Hubungan Variabel & Est. & S.E. & C.R. & P & Std. Est & Keterangan \\
\hline (H1) Kualitas Sistem $\rightarrow$ Penggunaan & .061 & .113 & .542 & .587 & .049 & Ditolak \\
(H2) Kualitas Sistem $\rightarrow$ Kepuasan Pemakai & .350 & .102 & 3.426 & $* * *$ & .331 & Diterima \\
(H3) Kualitas Informasi $\rightarrow$ Penggunaan & .016 & .116 & .139 & .889 & .012 & Ditolak \\
(H4) Kualitas Informasi $\rightarrow$ Kepuasan & .605 & .109 & 5.576 & $* * *$ & .539 & Diterima \\
Pemakai & & & & & & \\
(H5) Kualitas Layanan $\rightarrow$ Penggunaan & -.054 & .122 & -.442 & .659 & -.038 & Ditolak \\
(H6) Kualitas Layanan $\rightarrow$ Kepuasan & .396 & .109 & 3.630 & $* * *$ & .328 & Diterima \\
Pemakai & & & & & & \\
(H7) Penggunaan $\rightarrow$ Kepuasan Pemakai & -.613 & .100 & -6.144 & $* * *$ & -.721 & Ditolak \\
(H8) Kepuasan Pemakai --> Penggunaan & .742 & .118 & 6.293 & $* * *$ & .850 & Diterima \\
(H9) Penggunaan $\rightarrow$ Manfaat & .319 & .080 & 3.988 & $* * *$ & .289 & Diterima \\
$($ H10) Kepuasan Pemakai $\rightarrow$ Manfaat & .099 & .094 & 1.054 & .292 & .076 & Ditolak \\
\hline
\end{tabular}

Pengujian hipotesis dilakukan dengan menganalisis nilai Critical Ratio (CR) dan nilai Probability (P) yang dihasilkan dari perhitungan oleh AMOS, dibandingkan dengan batasan statistik yang disyaratkan, yaitu CR $>1,96$ dan $\mathrm{P}<0,05$ untuk nilai $\mathrm{P}[19]$. Bila hasil olah data memenuhi syarat, maka hipotesis bisa diterima. Dengan melihat hasil pada tabel 5 dapat diperoleh kesimpulan mana saja hipotesis yang ditolak dan mana yang diterima. Diketahui dari hasil analisis, hipotesis pertama (H1) ditolak yaitu tidak terdapat pengaruh kualitas sistem terhadap penggunaan SIKMA. Hasil ini sesuai dengan penelitian Wu dan Wang [20], yang membuktikan bahwa kualitas sistem merupakan hal yang vital namun tidak menjadi sesuatu yang penting ketika digunakan. Penggunaan SIKMA yang bersifat mandatori untuk pengelolaan data SPAMA sejauh ini memang sesuai kebutuhan saja, sehingga secara langsung kualitas sistem tidak berperan atau berpengaruh terhadap pengguna yaitu mahasiswa. Hasil dari hipotesis pertama berbanding lurus dengan hasil dari hipotesis $3(\mathrm{H} 3)$ dan hipotesis $5(\mathrm{H} 5)$. Kualitas informasi dan Kualitas layanan tidak memiliki pengaruh terhadap penggunaan, maka kedua hipotesis ini ditolak. Hasil ini sesuai dengan penelitian McGill et al. [21] dan Iivari [22] yang menyatakan bahwa kualitas informasi tidak memiliki pengaruh signifikan terhadap penggunaan. Penyajian informasi yang kurang menarik, relevansi informasi yang kurang tepat, dan bahasa yang tidak mudah dipahami merupakan kekurangan dari kualitas informasi yang dihasilkan oleh SIKMA. Sedangkan dari segi layanan, respon yang kurang tanggap menjadikan berkurangnya minat mahasiswa untuk menggunakan SIKMA untuk mengelola data SPAMA. Sifat mandatori dari SIKMA juga menjadi faktor yang dapat berpengaruh terhadap berkurangnya minat mahasiswa.

Ditolaknya ketiga hipotesis yang berkaitan dengan kualitas sistem, informasi dan layanan terhadap penggunaan berbanding terbalik dengan ketiga hipotesis lain mengenai pengaruh tiga konstruk tersebut terhadap kepuasan pemakai. Hipotesis 2 (H2) sejalan dengan Hipotesis 4 (H4) dan Hipotesis 6 (H6) yaitu adanya pengaruh kualitas informasi, kualitas sistem dan kualitas layanan terhadap kepuasan pemakai. Hasil penelitian ini sesuai dengan hasil penelitian Roldan \& Leal [2] serta penelitian Iivari [22] terdapat pengaruh yang signifikan dari kualitas informasi terhadap kepuasan pengguna sistem informasi. Penelitian lain yang sesuai dengan penelitian ini adalah hasil penelitian Roldan \& Leal [2] dan Budiyanto [11] yang menunjukkan adanya pengaruh signifikan kualitas sistem terhadap kepuasan pemakai. Dari segi kualitas layanan, penelitian oleh Lin [23] menunjukkan adanya pengaruh positif kualitas layanan terhadap kepuasan pemakai. Berdasarkan hasil analisis terhadap ketiga hipotesis tersebut, dapat disimpulkan bahwa jika sebuah sistem informasi dikembangkan dan dioptimalkan dengan maka dapat meningkatkan kepuasan pemakai. Dengan meningkatnya kepuasan pemakai, maka minat mahasiswa dalam menggunakan sistem informasi dari waktu ke waktu akan meningkat. Woodroof \& Kasper [24] dalam penelitiannya mengembangkan sebuah gagasan konsep untuk melihat dan mengetahui tingkat kepuasan pengguna dalam menggunakan sebuah sistem informasi. Dalam penelitiannya, sistem informasi dapat dikatakan sukses jika sistem informasi tersebut efektif dalam prosesnya dan hasil yang didapat efisien atau sesuai yang dibutuhkan pengguna dan dalam pengembangannya sistem informasi harus didesain untuk meningkatkan kepuasan pengguna. 
Selanjutnya adalah Hipotesis 7 dan Hipotesis 8 yang diajukan untuk membuktikan pengaruh antara penggunaan dan kepuasan pemakai. Khayun \& Rachtam [25] dalam penelitiannya menyatakan bahwa hubungan antara penggunaan dan kepuasan pemakai sangat erat. Pada sebuah proses, penggunaan harus berada sebelum kepuasan pemakai. Namun, dalam hubungan kausalnya, pengalaman positif pengguna akan meningkatkan kepuasan pemakai dan meningkatnya kepuasan pemakai juga akan meningkatkan intensitas penggunaan [5]. Teori tersebut berbanding terbalik dengan hasil analisis terhadap Hipotesis 7 dan 8. Hipotesis 7 pada penelitian ini yaitu adanya pengaruh positif penggunaan terhadap kepuasan pemakai ditolak. Sedangkan Hipotesis 8 yaitu adanya pengaruh positif kepuasan pemakai terhadap penggunaan diterima.

Berdasarkan hasil yang berbeda dari dua hipotesis ini, dapat disimpulkan bahwa kepuasan pemakai yang meningkat ketika pengguna menggunakan sistem informasi dengan kredibilitas yang tinggi, informasi yang dihasilkan dan layanan yang baik memiliki efek tidak langsung terhadap meningkatnya penggunaan. Namun, jika ketika pengguna mendapatkan pengalaman yang kurang baik selama menggunakan sistem, secara langsung akan mengurangi kepuasan pemakai. Oleh karena itu, untuk pengembangan lebih lanjut dari SIKMA, dibutuhkan pembenahan sistem sehingga ketika pengguna menggunakan sistem untuk kali berikutnya bisa mendapatkan pengalaman yang positif.

Manfaat bersih terdiri dari dua manfaat yaitu manfaat individu dan manfaat organisasi. Karena SIKMA hanya digunakan oleh mahasiswa maka penelitian ini hanya menganalisa dampak individu saja. Hipotesis 9 (H9) yaitu adanya pengaruh positif penggunaan terhadap manfaat diterima. Pengguna yang menggunakan SIKMA sebagai pengelolaan data SPAMA dengan intensitas penggunaan yang berkala dapat berpengaruh terhadap motivasi pengguna dalam mengikuti kegiatan nonakademik. Hal ini sesuai dengan penelitian Radityo \& Zulaikha [9] dikarenakan penggunaan sistem yang mandatori, penggunaan berpengaruh signifikan terhadap dampak individual. Penggunaan SIKMA yang mandatori dikarenakan wajibnya mahasiswa angkatan 2011-2015 untuk memiliki poin SPAMA, sehingga mahasiswa secara tidak langsung termotivasi untuk mengikuti kegiatan nonakademik. Dengan mengikuti kegiatan nonakademik ini, mahasiswa juga terasah soft skills yang dimilikinya. Hasil analisa hipotesis 9 ini berbanding terbalik dengan hasil analisa hipotesis 10. Hipotesis 10 (H10) yaitu adanya pengaruh positif kepuasan pemakai terhadap manfaat ditolak.

\section{Kesimpulan}

Ada 10 hipotesis yang dibentuk berdasarkan model DeLone dan McLean 2003 untuk menguji kesuksesan implementasi SIKMA. Berdasarkan pembuktian hipotesis menggunakan model SEM terdapat 5 hipotesis yang diterima dan 5 hipotesis yang ditolak. Berdasarkan hal tersebut dapat ditarik kesimpulan bahwa implementasi SIKMA belum bisa dikatakan sepenuhnya sukses. Tidak adanya pengaruh kualitas informasi, kualitas informasi dan kualitas layanan terhadap penggunaan merupakan faktor tidak suksesnya sistem. Mahasiswa sebagai pengguna tidak mendapatkan kepuasan menyeluruh dalam penggunaan sistem dan komunikasi antar dimensi dalam SIKMA tidak berjalan dengan baik. Pengalaman yang kurang baik yang didapat ketika pertama kali menggunakan SIKMA, dapat berpengaruh terhadap berkurangnya minat penggunaan. Oleh karena itu, diperlukan adanya peningkatan kualitas sistem, kualitas layanan dan kualitas informasi agar memberikan pengaruh positif pada kepuasan pengguna, yang secara langsung akan memberikan pengaruh terhadap peningkatan minat penggunaan dan memberikan manfaat-manfaat bagi mahasiswa sebagai pengguna.

\section{Referensi}

[1] F. Masaru and M. Akira, "A Study in the 'Flexibility' of Information Systems (Part 1): Why Do They Need to Be Flexible?,” Int. J. Bus. Manag., vol. 8, no. 20, pp. 48-61, 2013.

[2] J. L. Roldán and Antonio Leal, "A Validation Test of an Adaptation of the DeLone and McLean's Model in the Spanish EIS Field," in Critical reflections on information systems: a systemic approach, 2003, pp. 66-84.

[3] Y. Li, Y. Duan, Z. Fu, and P. Alford, "An empirical study on behavioural intention to reuse elearning systems in rural China," Br. J. Educ. Technol., 2012.

[4] Awangga Febian Surya Admaja, "Analisis Kesuksesan Sistem Informasi Manajemen Sumber

Rahayu, Apriliyanto, Putro (Analisis Kesuksesan Sistem Informasi Kemahasiswaan (SIKMA) dengan Pendekatan Model DeLone dan McLean) 
Daya dan Perangkat Pos dan Informatika (SIMS)," Bul. Pos dan Komun., vol. 12, no. 2, 2014.
W. H. DeLone and E. R. McLean, "The DeLone and McLean model of information system success: A ten-year update," in Journal of Management Information Systems, 2003.

[6] W. H. DeLone and E. R. McLean, "Information systems success: The quest for the dependent variable," Inf. Syst. Res., 1992.

[7] C. E. Shannon and W. Weaver, "The mathematical theory of communication.," Univ. Illinois Press, 1963.

[8] R. O. Mason, "Measuring information output: A communication systems approach," Inf. Manag., 1978.

[9] D. Radityo and Zulaikha, "Pengujian Model DeLone and McLean Dalam Pengembangan Sistem Informasi Manajemen ( Kajian Sebuah Kasus )," Simp. Nas. Akunt. X, 2007.

[10] Islam Muhammad Salim, "Analisis Kesuksesan Sistem Informasi Perpustakaan Senayan dengan Pendekaran Model DeLone dan McLean di SMK Muhammadiyah 3 Yogyakarta," 2009.

[11] Budiyanto, "Evaluasi Kesuksesan Sistem Informasi dengan Pendekatan Model DeLone dan McLean: Studi Kasus Implementasi Billing System di RSUD Kabupaten Sragen," 2009.

[12] S. Purwaningsih, "Analisis Kesuksesan Penerapan Sistem Informasi pada Sistem Informasi Pelayanan Terpadu (SIPT) Online (Studi Pada PT Jamsostek ( PERSERO))," Aset,ISSN 1693$928 X, 2010$.

[13] N. Urbach, S. Smolnik, and G. Riempp, "A methodological Examination of empirical Research on Information Systems Success: 2003 to 2007," Proc. 14th Am. Conf. Inf. Syst., 2008.

[14] Y. S. Wang and Y. W. Liao, "Assessing eGovernment systems success: A validation of the DeLone and McLean model of information systems success," Gov. Inf. Q., 2008.

[15] Singgih S, Analisis SPSS pada Statistik Parametrik. Jakarta: PT. Elex Media Komputindo, 2012 .

[16] K. EN, Pengaruh Keterampilan Mengajar Guru terhadap hasil belajar siswa pada mata pelajaran Akuntansi. Universitas Pendidikan Indonesia, 2015.

[17] Fuad and Ghozali, SEM Teori dan Konsep dengan Program LISREL 8.80. Semarang: BPUndip, 2008.

[18] J. F. Hair, W. C. Black, B. J. Babin, and R. E. Anderson, "Multivariate Data Analysis," Vectors. 2010.

[19] Ferdinand A, Structural Equation Modeling dalam Penelitian Manajemen. Semarang: Universitas Diponegoro, 2000.

[20] J. H. Wu and Y. M. Wang, "Measuring KMS success: A respecification of the DeLone and McLean's model," Inf. Manag., 2006.

[21] T. McGill, V. Hobbs, and J. Klobas, "User-developed applications and information systems success: A Test of DeLone and McLean's model," Inf. Resour. Manag. J., 2003.

[22] J. Iivari, "An Empirical Test of the Model of Information System Success," DATA BASE Adv. Inf. Syst., 2005.

[23] J. Lin, "An exploration of the principles underlying redundancy-based factoid question answering," ACM Trans. Inf. Syst., 2007.

[24] Jonathan B. Woodroof and George M. Kasper, A Conceptual Development of Process and Outcome User Satisfaction. 1998.

[25] V. Khayun and P. Ractham, "Measuring e-excise tax success factors: Applying the DeLone \& McLean information systems success model," in Proceedings of the Annual Hawaii International Conference on System Sciences, 2011. 